\title{
Hope amidst Despair: Revisiting John Steinbeck's Novel The Grapes of Wrath in the times of COVID-19 pandemic
}

\author{
M. Shanthi ${ }^{1} \&$ Ms. Lizella Faria Gonsalves ${ }^{2}$ \\ ${ }^{1}$ Associate Professor, Department of English, Dnyanprassarak Mandal's College and \\ Research Centre, Assagao, Mapusa, Goa. ORCID id-oooo-0oo2-6114-2366. Email: \\ shanthimuninathan@gmail.com \\ ${ }^{2}$ Assistant Professor, Department of English,Dnyanprassarak Mandal's College and \\ Research Centre, Assagao, Mapusa, Goa. ORCID id-oooo-ooo1-5699-5412. Email: \\ lizella.gonsalves@gmail.com
}

\begin{abstract}
Death has always been co-existing amidst all life-forms. But when it turns its vehemence on humanity with all its force by means of pandemics, epidemics, wars or natural calamities then it gets its due, acting as a great equalizer. The Catastrophic Corona, today has revolutionized the face of humanity and the Existential Angst is acutely felt. The boundaries and demarcations of caste, creed, religion, region and gender have been ignored by the virus levelling all to the mercy of greater powers. The subversion of capitalism and deconstruction of the binaries like positive and negative, the physical and the virtual have induced discourse subjected to critical study. Since Literature and Life has always gone hand-in-hand, it is natural to witness the saga of human turmoil and suffering being portrayed in literary works. Albert Camus's novel, The Plague is a classic example of the precariousness of human life and existential isolation. But as devastating as a pandemic or an epidemic is, equally ravaging are the forces of nature and crippling circumstances which lead to unsurmountable suffering and pain. John Steinbeck's The Grapes of Wrath is an evocative saga of resilience and survival amidst the onslaught of the Dust Bowl and the Great Economic Depression. The Joad family in the novel represents a microcosm of the universal suffering and their story finds echoes in the hearts of many in such times as the present COVID-19 crisis. This paper aims at a study of the socio-economic and psychological factors affecting humanity during crisis through the study of John Steinbeck's The Grapes of Wrath. It would be an endeavor to evaluate the changes and adapt to the 'New Normal.'
\end{abstract}

Keywords: Pandemic, Existentialism, Economic Crisis, Deconstruction, Despair and Hope.

\section{Introduction}

Jean Paul Sartre once quoted "Life begins on the other side of despair" and this finds itself proved right as humanity is struggling to cope with the onslaught of the COVID-19 pandemic. The existential angst is acutely felt as life and the world economy has seen its worst days. The relentless onslaught of the virus rendering all human efforts useless is evocative of the suffering and misery of people world-wide. Uncertainty of the future looms large despite actions being initiated to curb the fatalities and make the economy stand on its feet. There is death, despair and anxiety bringing the whole humanity under its grip. Significant questions posed by Existentialists find their echoes in these times-

(C) AesthetixMS 2020. This Open Access article is published under a Creative Commons Attribution Non-Commercial 4.o International License (http://creativecommons.org/licenses/by-nc/4.o/), which permits non-commercial re-use, distribution, and reproduction in any medium, provided the original work is properly cited. For citation use the DOI. For commercial re-use, please contact editor@rupkatha.com. 
"Don't you have the impression that we are living ...if we can call that living...in a broken world? Yes, broken like a watch has stopped. Its mainspring no longer works. To all appearances nothing has changed. Everything is in place. But if you put that watch to your ear...you hear nothing. Remember, the world, or what we call the world, the human world...used to have a heart. But it seems that heart has stopped beating..." (Marcel, 1998, 31-42).

The existential crisis is palpable with changes surging humanity on a quest for survival. Change is the constant in the present times and as welcoming it would otherwise be, it brings along with it an overwhelming sense of anxiety. But, in the changing tide of affairs, relooking at things and ideas from a different perspective is needed to maintain equanimity. In fact, even anxiety produces the necessity for self-introspection. It is not surprising that history repeats itself and impresses upon humanity that Death is a resident among all Life forms and therefore would make its presence intensely felt from time to time.

Throughout human history, the world has witnessed significant and life changing calamities and disasters which has constantly allowed humanity to realize the precariousness of life. All of these natural and man-made disasters have brought home the truth that human existence depends on the delicate balance of natural, scientific and supernatural forces. Any imbalance might result in cataclysmic events. And in the face of any calamity, people lose their equilibrium, and struggle to find their moorings. Deprived of security, human beings are left to ponder over their state of existence and the meaning of life. As Karl Jaspers in Philosophy, Volume 2 states,

"The discontent of possible self-being has broken through mundane existence and cast the individual back upon himself, back to the origin that lets him deal with his world and....realize his existence" $(1969,9)$.

Dealing with any tragedy requires strength and courage. In the face of insurmountable difficulties with others facing the same problems, poses a challenge. With limited options, death seems an easy way out but the urge to survive is equally persistent. Throughout the dark episodes of disasters and calamities, human resilience has retained its glimmer of hope. According to Kubler Ross Model, a person facing any misfortune undergoes five major stages- (i) Denial (ii) Anger (iii) Bargain (iv) Depression (v) Acceptance (Five stages of Grief)._Application of this theory to the present COVID-19 crisis seems plausible with reports indicating the increasing number of cases of depression and domestic violence. The impact of tragic events certainly takes a toll on the psychological well-being of a person. A prolonged period of denial leads to heightened state of sadness and builds up anger. Depression therefore seeps in a mind soaked with despair which can only be relieved by accepting the situation. Acceptance of the situation produces a hopeful despair. Hope, therefore resides in resilience which envisages a better tomorrow.

All good literature contains ideas-expressing universal truths holding the potential to activate hope and revaluate life. Such ideas have changed the trajectory of many lives. Literature always anticipates what is going to come, it does not copy but moulds it to its purpose. The literary texts reflect the age and create new narratives conducive to innovation and change. Therefore, assessing literary works offers the scope of providing insights about life in all its dimensions.

The COVID-19 pandemic provides a comparative case scenario as depicted in many literary works like Albert Camus's The Plague or Daniel Defoe's A Journal of the Plague Year. Albert Camus in his novel, The Plague, presents the horrific scenario of the devastation caused by the epidemic of Plague in the fictional town of Oran. It is interesting that death, devastation and suffering produces a remarkable change in the behaviour of people. The obsession with self- 
preservation renders people helpless bringing to the fore even abhorring attitudes. Camus also makes the proposition that "everyone has inside it himself this plague, because no one in the world, no one, can ever be immune" (Camus 2009, 195).

Likewise, A Journal of the Plague Year, too recounts incidents of suffering and death which occurred during the outbreak of the plague in London in 1665-1666. Many scenes portrayed in the book give a sense of déjà vu in light of the present COVID-19 scenario.

“...seeing they were all dead, and were to be huddled together into the common Grave of Mankind, as we may call it, for here was no difference made, but poor and rich went together. There was no other way of burials, neither was it possible there should, for coffins were not to be had for the prodigious numbers that fell in such a calamity as this" (Defoe 1959, 63).

"It is true, hundreds, yea, thousands of families fled away at this last Plague, but then of them, many fled too late and not only died in their flight, but carried the Distemper with them into the countries where they went, and infected those whom they went among for safety..." (Defoe 1959, 189).

Another classic Srikant by Sharat Chandra Chattopadhyay highlights the grim picture of life amidst an epidemic-

“.. this is the time that everyone was interested in preserving their own lives. No mother, no father, no wife, no children, no relation, no friends, no acquaintances. It is just everyone to himself. ...a selfish age of self- preservation, nursing the infected means infection and ultimate death" $(1944,275)$.

The fear of death and self-preservation is the common thread in all such narratives about epidemics and disasters. The first impact of any such catastrophe is on the human mind attacking the thoughts, senses and the actions. The resulting changes lead to a dichotomy between the real and the imagined. Fear, anxiety and social unrest gradually gathers momentum and there's a polarization which occurs leading to systematic changes in the socio-economic set-up.

The COVID-19 pandemic has resulted in binaries like, Local and Migrants, Indoor and Outdoor, Positive and Negative, Physical and Virtual and Social and Physical distancing. The need for maintaining social distancing as a form of self-preservation is a requisite in the present scenario and therefore, staying indoors and living in a virtual world has become the 'New Normal'. The breaking down of the prior order of proximities have facilitated a dynamic change in the lifestyle of the people. There has also been marked alteration in the people's perception regarding spatial factors demarcating people as locals and migrants.

The migrant crisis in India during the lockdown presented a heart-rending scenario of the propensity of the damage caused by the pandemic. Their story is a universal story raising humanitarian concerns and the resilience of the human spirit. For every villain, there is always a hero; the pandemic has brought to light numerous instances of discrimination against the COVID-19 patients and even the health workers and doctors, there have been cases of violence and humiliation, but, on the contrary, there have also been acts of surpassing kindness and generosity performed by mere 'ordinary' people. It is these benevolent deeds which can be later recalled and offer consolation in the dark period of despair.

The migrant crisis also brought to the fore the worsening state of world economy which is reeling under the relentless onslaught of the corona virus. Anne Case and Deaton in Deaths of 
Despair and the future of Capitalism highlight the flaws in capitalism and its effects on the working class. They present a realistic world view,

"Jobs are not just the source of money; they are the basis for the rituals, customs, and routines of working-class life. Destroy work and, in the end, working class life cannot survive. It is loss of meaning, dignity, of pride, and of self-respect" $(2020,16)$.

Though the book was written prior to the outbreak of the pandemic with the focus on America, yet, the alarming condition of the working class and the increasing cases of unemployment aptly captures the grim situation in which we are all in today.

As evocative has been the literature portraying the horrors of epidemics and human suffering, John Steinbeck's The Grapes of Wrath is equally incisive in its depiction of the struggle faced by the migrant labourers due to the Dust Bowl in America in the backdrop the Great Economic Depression. His reason to write this novel was to vocalize the pitiable condition of the real people who were uprooted and became vagrants due to the landowners and the Banks (who in turn were rendered helpless by the Depression). The question however lies in the fact that who were the victims and how humanely could the situation have been addressed.

\section{The Grapes of Wrath}

The Grapes of Wrath won the National book award, Pulitzer Prize and eventually won the Nobel Prize too. Based on Steinbeck's visit to the camps and shared experiences with the migrants, the novel is a representation of the ordeal faced by the displaced families struggling to retain their identity and dignity. The drought at Oklahoma compels the tenant farmers to leave their land. The hope of better prospects makes them embark on the journey to the 'Promised Land'- California. The narrative focuses on the Joad family and the challenging hardships they face as they journey on Highway 66 experiencing death of Grandpa and Grandma, loss and separation of other family members. Their arrival in California and the pitiable state to which they are reduced presents a sympathetic picture of their sense of indignation and injusticescrambling for jobs and surviving on meagre ration which later incites Jim Casey and Tom to rebellion. Casey's accidental death and Tom's life as a fugitive further aggravates their misery. However, their fortitude and determination to survive proclaims a tale of heroism and Hope amidst Despair with the novel ending on an unsettling yet optimistic note of Rose of Sharon breast-feeding a starving man after delivering a still-born child. The novel raised awareness about the devastation caused by the Dust Bowl to the farmlands and plight of the migrant workers with political and activist movements arising as result of it.

The situation of Covid-19 can be paralleled with the circumstances caused due to the drought in Oklahoma, the monster 'Corona' can be equalized with the bank officers and large corporations. The hostility which the people face as they travel to California is akin to the discrimination and prejudice in the minds of most residents concerning the migrants. In the larger spectrum of the pandemic, the human life appears trivial and the humanity at large cannot escape from the virus. Brian Railsback in his article The Darwinian Grapes of Wrath states this truth,

"The novel presents a large picture in which humans are only a small part; in the great natural scheme of sky and land, of rain, wind, and dust" $(2007,151)$.

People were not prepared to face such a calamity as most of the people had a qualitative life. With the sudden outbreak of the pandemic, the unexpected happened and people had to witness suffering, death and despair. 


\section{Hope and Despair}

Life is meaningless without a sense of belongingness, as a sense of identity builds communities and fosters relationships. The displacement results in a loss of identity for the people as Ma Joad says, "They was the time when we was on the lan'. They was a boundary to us then... We was the fambly- kinda whole and clear. An' now we ain't clear no more." (Steinbeck 1992, 239)

When the truck drivers come to dismantle the land under the directives of the Banks, the farmers' heart cries while witnessing their lands being taken away by the big monsters. Attachment to the land runs deep as one of the farmer says,

"It's our land....we were born on it, and we got killed on it. Even if it's no good it's still ours...that's what makes ownership. Not a paper with numbers on it" $(1992,35)$.

The Dust Bowl, drought and the Banks in the backdrop of the period of Depression brought the worst affected people to utter ruin and despair. The Great Economic Depression was one of the blackest periods in the history of the world dismantling the very fabric of the society. Likewise, unimaginable economic strain due to COVID-19 has brought the world to a standstill. Many have lost their jobs and business owner have suffered tremendous losses. The financial strain compounded by the psychological dilemma has resulted in the quest for survival. In an article Job Loss most severe immediate impact of Covid -19: Survey which was quoted had the same concept that "The loss of employment was considered as the most severe immediate impact of crisis" (Economic Times, $11^{\text {th }}$ June, 2020).

The novel portrays this predicament as the people are uprooted from their land and walk a nomadic path with only Hope as their guiding light. They hope for a better life but what they get is humiliation and exploitation. The worst tragedy they encounter is, the inhumanity of their fellow human beings. The sense of mortification and resentment is palpable as we realize their sad saga-a sudden blow changed their destiny! Understanding their story through the Kubler Ross model offers a sympathetic insight, however getting fixated on any one stage would proves disastrous. So also, the acceptance would lead either to adapting to change or bringing change through rebellion or activism.

The labelling of these newcomers derisively as 'Okies' and the ramshackle camps termed 'Hooverville' with atrocious acts of dumping potatoes in the rivers and burning the fruits while people watch these with hungry eyes scream aloud of inhumanity.

"There is a crime here that goes beyond denunciation. There is a sorrow here that weeping cannot symbolize. There is a failure here that topples all our success. The fertile earth, the straight tree rows, the sturdy trunks, and the ripe fruit. And children dying of pellagra must die because a profit cannot be taken from an orange. And coroners must fill in the certificates-died of malnutrition-because the food must rot, must be forced to rot" (Steinbeck 1992, 365).

The division caused by class and economy is the root cause of most of the evil. Placed in arbitrary system of operation and being at the mercy of the Capitalists results in psychological and emotional strain. In the novel, each family member fights the despair through their own level of perception and understanding. Pain runs through their lives but, the endearing quality of these suffering people lies in their sense of dignity and camaraderie.

Although self-preservation is the key in times of crisis, with social-distancing being the key 'mantra', the irony however lies in the fact that we can survive only as a community. This sense of 
belongingness and uniting for a common cause is the beginning of the realization of the human potential for goodness.

The indifference of the truck drivers and the land owners of California who are more worried about the profit than the misery of the daily wage laborers is saddening. But against this onslaught of injustice, The concept of 'I' changes into 'we.' Brian Railsback in The Darwinian Grapes of Wrath comments,

"The migrant workers show a sense of compassion for their fellows that bind them together and eventually ensure their existence in a hostile environment, for the cooperation that grows out of sympathy is the greatest threat to the owners" $(2007,155)$.

It is the sign of positivity that amidst hunger and deprivation of basic amenities, hope shines out. When the men get into depression and despair, Ma Joad encourages them,

"You ain't got the right to get discouraged. This here fambly's goin' under. You jus' ain't got the right" (Steinbeck 1992, 366).

The psychological effect of the trauma of death, loss and anxiety is palpable in the survivors of any tragedy. Sonali Acharjee in her article, The Covid Survivors in India Today highlights the need to draw on the inner strength to fight the battle:

"They have been to the edge of the Covid abyss and back. Some got away easy, others struggled with the stigma, the isolation and the disease. At the other side of the crisis now, all of them have one thing to say: whatever it may do to your body, don't let Covid mess with your mind" (June 22, 2020, 34).

\section{Human Resilience}

Resilience is the key factor which runs throughout the novel. Michael Rutter in his article Implications of Resilience Concepts for Scientific Understanding defined resilience as "an interactive concept that is concerned with the combination of serious risk experiences and a relatively positive psychological outcome despite those experiences" $(2006,2)$

In the novel Ma Joad takes up all the challenges with a clear head. Pragmatic ideology brings Ma Joad to look life as it is and tries to unite the family in spite of the hurdles which they face throughout their journey and life at the various camps. She stabilizes and unifies her family. When Pa Joad fails in his role as the head of the family, Ma Joad shifts from patriarchal submission to matriarchal domination in order to make the family to proceed further. Jean Paul Sartre, the existential philosopher says,

"Choice is therefore central to human existence and it is inescapable and even refusal to choose is a choice" (Being and Nothingness, 2003).

The choice of being the facilitator makes Ma Joad a strong character, and Hope the driving force of their life, although nothing positive happens to them. Grandpa and Grandma die on their way. Noah leaves them, Rose of Sharon's husband, Connie abandons her, Casy gets murdered, Tom becomes a murderer, Al prefers to leave the family, Rose of Sharon gives birth to a still born baby, yet a lingering shadow of hope clings in their heart which creates a feeling of close proximity with each another. Their faith provides them with moral strength.

It is Hope which carries the Joads and the others through all the hardships. Hope to get better life in California. When the drought begins, the farmers hope that it would pass by and they would survive. When the women find their men are not broken, they have hope to survive. The fight for survival is always shown through Ma Joad- 
"Why, Tom-us people will go on livi' when all them people is gone. Why, Tom, we'are the people that live. They ain't gonna wipe us out. Why, we're the people-we go on" (Steinbeck 1992, 293).

Scenes from The Grapes of Wrath bring reminisces of the Indian migrants' Exodus with images of some dying of hunger and dehydration during the lock-down. Aroon Purie, the Editorin-Chief, India Today stated in his editorial:

“The Migrant's exodus could add to our ongoing economic crisis. Rural India cannot absorb them but needs their remittances. Urban India needs them because their absence could delay economic revival. If migrants don't return to their workplace, a human tragedy could well become an economic one" (June 8, 2020, 3).

Their woes are those of universal suffering and pain and their struggle for survival is an appeal to the whole humanity. Real stories require real heroes and for the migrant crisis, it would definitely be the responsibility of the leaders to assuage the woes of these grieving souls.

In the novel, Rose of Sharon is the incarnation of hope and survival for the future as she selflessly breast feeds a starving man after she delivers a still-born child. It is remarkable, for she steps down from her self-centeredness and stoops down to administer to someone in an equally pathetic state or rather worse. The message is simple-Life is precious and it takes humanity to revive a human.

McKay comments about the end of the novel,

"Those who survive will come to realize that group action can have an effect on the monstrous ideology that threatens their existence. But first they must survive; and the women are at the center of making that survival possible" (The Portrayal of Ma Joad in John Steinbeck's The Grapes of Wrath, 2007, 103).

Resilience is the need of the hour during the pandemic. The diligent people do not slosh in the disappointments in life; they would rather concede to the circumstances in which they are pushed to and grow from the errors which they have committed. Tom Joad decides no longer to be a silent spectator to the injustice around him and following Jim Casey's teaching sets out to a course of action, which compels him to say-

"I'll be ever'where-wherever you look. Wherever they's a fight so hungry people can eat, I'll be there. Wherever they's a cop beatin' up a guy, I'll be there" (Steinbeck 1992, 439).

This speaks of courage and a new-found optimism to battle the 'monsters' threatening their very existence. Tom's strong individuality speaks a language of humanism. Adapting to the 'New Normal' would entail recognizing the social spirit and embracing all human beings as part of one family. Another equally powerful symbol of resilience is the survival of the land turtle and Ma Joad's declaration- "We're the people-we go on" (293).

\section{Conclusion}

There is no immediate relief for the present pandemic till the arrival of the vaccine. In the meantime, it is a struggle for survival and adapting to change. The pandemic has provided the people with the chance to reevaluate their priorities. Rose of Sharon's acceptance of Ma Joad's request at the end of the novel is powerful. The ability to move beyond the binaries of local and migrant, rich and poor and focus on 'we' the people facing the same storm would help in easing the building psychological and economic burdens of each other. Coping with the changes and adapting to the 'New Normal' where everything is either virtual or distant is part and parcel of the 
life in times of a pandemic, but the ability to retain hope amidst the darkest phase of one's life and in fact of the whole humanity is a lesson to be learnt by all. The shared experiences and miseries result in creating a bond which can be worked upon to resist despair and depression. The novel is a starling example of human resilience, as Peter Lisca in The Grapes of Wrath as Fiction says,

"The Grapes of Wrath represents the indomitable spirit of man that spirit which remains whole by resisting despair and resignation in the face of drought of life, physical, privation, exploitation, persecution, the tyranny of name calling and the uprooting of the very way of life. Out of these shared miseries there grows as spirit to the possessive change" $(1959,298)$.

Fear and anxiety are the prime agents of depression and the 'virus' of negativity could kill a lot more than the actual virus. Therefore, broadening the limited vision of one's own pain and suffering would entail viewing Life in its whole dimension and realize that the whole humanity is interconnected and what affects one naturally would affect others. The picture of stark simplicity and utter desolation at the end of the novel as Steinbeck has portrayed it touches the heartstrings and reiterates the message that human life though evanescent, is worth living.

"They squatted on their hams and looked out over the flooded land. And they were silent. And sometimes they talked very quietly.

No work till spring. No work.

And if no work-no money, no food.

Fella had a team of horses, had to use 'em to plow an' cultivate an' mow, wouldn' think a turnin' 'em out to starve when they wasn't workin'.

Them's horses-we're men" (Steinbeck 1992, 454).

Change in perception and transformation in value systems could be a step in the direction of building bridges torn apart by selfishness led by pain and suffering. As Steinbeck in his Nobel Prize Acceptance Speech stated-

"The ancient commission of the writer has not changed. He is charged with exposing our many grievous faults and failures, with dredging up to the light our dark and dangerous dreams for the purpose of improvement...the writer is delegated to declare and to celebrate man's proven capacity for greatness of heart and spirit - for gallantry in defeat - for courage, compassion and love. In the endless war against weakness and despair, these are the bright rally-flags of hope and of emulation... Fearful and unprepared, we have assumed lordship over the life or death of the whole world - of all living things. The danger and the glory and the choice rest finally in man" (Banquet Speech, 1962).

It is therefore to be hoped that the end of this ordeal would lead us all to a dawn of a new humane civilization.

\section{References:}

Acharjee, Sonali. “The Covid Survivors." India Today Vol. XLV No: 25. June 22, 2020 pp. 34.

Camus, Albert (2009). The Plague. Australia: Penguin Books.

Case, Anne., Deaton, Angus. (2020). Deaths of Despair and the Future of Capitalism. New Jersey: Princeton University Press.

Chattopadhyay, Chandra, Sharat. (1944). Srikant. Vatsyayan, Sachchidananda (Trans.), New Delhi: Penguin Books.

Defoe, Daniel. (1959). A Journal of the Plague Year. London: Bestseller Library. 
"Job Loss most severe immediate impact of Covid -19: Survey." Economic Times, (June 11, 2020). https://m.economictimes.com.

Jaspers, Karl. (1969). Philosophy, Vol 2. Chicago: University of Chicago Press.

Lisca, Peter. (1959). The Grapes of Wrath as Fiction PMLA LXXII (March, 1959) pp. 296-309.

Marcel, Gabriel. (1998). The Broken World. Wisconsin: Marquette University Press.

McKay, Y, Nellie. (2007). “The Portrayal of Ma Joad in John Steinbeck's The Grapes of Wrath.” John Steinbeck's The Grapes of Wrath. Bloom, Herold. (Ed.), New Delhi: Viva Books Private Limited. pp. 93-112.

Purie, Aroon. "Editorial." India Today Vol. XLV No: 23. June 8, 2020 pp. 3.

Railsback, Brian. (2007). "The Darwinian Grapes of Wrath." John Steinbeck's The Grapes of Wrath. Bloom, Herold. (edi.). New Delhi: Viva Books Private Limited. pp. 149-158.

Ross, Kubler., Elsabeth, Kessler. David. Five Stages of Grief. https://grief.com/the-five-stages-of-grief. Accessed on August $29^{\text {th }}, 2020$.

Rutter, Michael. (2006). "Implications of Resilience Concepts for Scientific Understanding." Annals of the New York Academy of Sciences, 1094, pp. 1-12.

Satre, J.P. (2003). Being and Nothingness. H.E. Barness (Trans.). New York, London: Routledge. Google Scholar.

Steinbeck, John. (1992). The Grapes of Wrath. USA, Penguin Books.

Steinbeck, John. (1962). "Banquet Speech." https://www.nobelprize.org/prizes/literature/1962/steinbeck/25229-john-steinbeck-banquetspeech-1962.

Dr. M. Shanthi: Teaching Literature and Language at the undergraduate college for twenty- five years. Researched on Campus Politics for the doctoral degree. Area of specialization are Subaltern Literature, Feminism, Goan Writing, Literature of the Diaspora and Indian Writing in English. Areas of interest include Eco-Feminism, African Literature and American Literature. Co-authored a text book titled Spoken English for the first year Commerce students. Edited a book titled Subaltern Reflections in Indian Writing in English and in Translation. Editor-in-chief of the college magazine for the past 15 years.

Ms. Lizella Gonzalves: Teaching at the undergraduate college for 10 years. Her area of specialization are British Literature, American Studies and Literature of the Diaspora. Editor of the College Newsletter and presently working on a Minor Research Project on the works of Agatha Christie. 